\title{
PENINGKATAN HASIL BELAJAR MODAL AUXILIARY MELALUI PENGGUNAAN FLIPPED CLASSROOM TARUNA TEKNIK PESAWAT UDARA ANGKATAN II POLTEKBANG SURABAYA
}

\author{
Fatmawati $^{1}$ \\ 1)Politeknik Penerbangan Surabaya \\ J1. Jemur Andayani I, No. 73 Surabaya 60236 \\ Email : fatmawati.0280@gmail.com
}

\begin{abstract}
ABSTRAK
Pembelajaran yang dirancang oleh dosen harus menggunakan metode yang sesuai dengan situasi atau kondisi pembelajaran, media yang digunakan dan kompetensi yang ingin dicapai sehingga tercipta pembelajaran efektif, efesien dan menyenangkan bagi taruna yang belajar dan pada akhirnya taruna mendapatkan pengalaman yang bermakna bagi dirinya. Peneliti ingin mengetahui peningkatan hasil belajar Modal Auxiliary melalui penggunaan Flipped classroom taruna Teknik Pesawat Udara Angkatan II C Poltekbang Surabaya.

Saat belajar Modal Auxiliary seringkali taruna melakukan kesalahan saat membuat dan menggunakan kata - kata tentang spelling, pronounciation, intonasi, dan kosa kata reading. Hal ini dikarenakan dosen tidak tepat dalam memilih metode pembelajaran. Permasalahan mendasar dalam penelitian ini adalah sebagian besar taruna Teknik Pesawat Udara Angkatan II C Poltekbang Surabaya Tahun Pelajaran 2016/2017 kurang mampu dalam Modal Auxiliary. Tujuan yang diharapkan dari penelitian ini adalah untuk mengetahui apakah penggunaan Flipped classroom dapat meningkatkan hasil belajar Modal Auxiliary taruna Teknik Pesawat Udara Angkatan II C Poltekbang Surabaya tahun pelajaran 2016/2017.

Penelitian ini menggunakan penelitian tindakan karena penelitian tindakan adalah merupakan penelitian yang lebih sesuai dengan tugas pokok dan fungsi dosen, meningkatkan kualitas pembelajaran, meningkatkan kualitas taruna, serta mencapai tujuan pembelajaran atau pendidikan. Dalam penelitian ini yang menjadi subyek penelitian adalah 24 taruna Teknik Pesawat Udara Angkatan II C Poltekbang Surabaya Tahun Pelajaran 2016/2017. Penelitian ini dilaksanakan pada bulan Februari 2018. Metode pengumpulan data pada penelitian ini adalah observasi, tes, wawancara, dan catatan lapangan. Teknik analisis data yang dipergunakan adalah reduksi data, penyajian data, penarikan simpulan, serta verifikasi refleksi

Berdasarkan pengamatan dalam pembelajaran pada siklus pertama diperoleh data hasil belajar taruna rata-rata 71,67 pada siklus pertama ini yang tuntas ada 13 taruna $(54,17)$ yang tidak tuntas ada 11 taruna $(45,83 \%)$. Berdasarkan pengamatan pembelajaran pada siklus kedua hasil belajar taruna rata-rata 86,67 dan pada siklus kedua yang tuntas ada 24 taruna $(100 \%)$. Kualitas pembelajaran siklus pertama memperoleh skor 3 (baik), dan siklus kedua memperoleh skor 4 (sangat baik).
\end{abstract}

Kata Kunci: Flipped classroom, Hasil Belajar Bahasa Inggris, Modal Auxilary

\section{PENDAHULUAN}

Komunikasi yang diharapkan pada pelajar bukan hanya pada komunikasi lisan (speaking) tetapi juga komunikasi secara tertulis (writing) yang di dalamnya mencakup pemilihan kata pada suatu kalimat dengan kalimat lain yang dapat mempengaruhi makna yang terdapat dalam suatu kalimat atau teks (Latif, 2015:225). Dibandingkan dengan ketiga kemampuan lainya (Speaking, Reading, dan Listening), kemampuan menulis (writing) dianggap lebih sulit dikuasai oleh pembelajar bahasa kedua. Dari beberapa kemampuan 
kebahasaan (Speaking, Reading, Listening, dan Writing), menulis bukanlah suatu pekerjaan yang mudah dan yang menjadi salah satu penyebab utama dalam pembelajaran bahasa asing di Poltekbang Surabaya.

Taruna dalam berkomunikasi baik lisan maupun tertulis perlu memahami modal auxilary. Subklasifikasi kedua dari kata kerja bantu, alat bantu modal, terdiri dari item berikut: can, could, may, might, must, shall, should, dan will (Kamuh, 2017:3). Pembelajaran modal untuk taruna Poltekbang Surabaya ini perlu memanfaatkan Flipped classroom. Flipped classroom merupakan model pembelajaran dengan cara meminimalkan jumlah instruksi langsung tapi memaksimalkan interaksi satu-satu. Strategi ini memanfaatkan teknologi yang mendukung materi pembelajaran tambahan bagi taruna yang dapat diakses secara online maupun offline kapanpun dan dimanapun. Sedangkan waktu pembelajaran di kelas digunakan taruna untuk berkolaborasi dengan rekan-rekan sekelas, keterampilan praktik dan menerima umpan balik tentang kemajuan mereka.

Model Flipped classroom memberikan apa yang umumnya di lakukan di kelas dan apa yang umumnya dilakukan sebagai pekerjaan rumah kemudian dibalik atau ditukar. Sebelumnya siswa datang ke kelas untuk mendengarkan penjelasan guru selanjutnya mereka pulang untuk mengerjakan latihan soal. Sekarang yang terjadi adalah siswa membaca materi, melihat video pembelajaran sebelum mereka datang ke kelas dan mereka mulai berdiskusi, bertukar pengetahuan, menyelesaikan masalah, dengan bantuan siswa lain maupun guru, melatih siswa mengembangkan kefasihan prosedural jika diperlukan, inspirasi dan membantu mereka dengan proyek-proyek yang menantang dengan memberikan kontrol belajar yang lebih besar (Damayanti, 2016:3). Kompetensi adalah keseluruhan sikap, pengetahuan, dan keterampilan yang dilakukan secara berimbang sehingga dapat digunakan untuk menentukan posisi relatif setiap peserta didik terhadap standar yang telah ditetapkan (Kemdikbud, 2013).

Dosen memegang peranan penting bagaimana taruna belajar. Dalam ruang lingkup teknologi pembelajaran, istilah belajar dianggap mengacu kepada kegiatan manusia untuk berkembang dan meningkatkan kualitas kinerja yang bersifat universal (Tegeh, 2010:1). Kita jangan sampai menggunakan sistem tradisional yang sudah kedaluarsa. Efektifitas dosen mengajar dapat dilihat seberapa besar taruna memperoleh pengetahuan baru (Muchith, 2008:37). Dosen adalah pribadi kunci di kelas karena besar pengaruhnya terhadap perilaku dan belajar para taruna, yang memiliki kecenderungan meniru dan beridentifikasi (Hamalik, 2012:40). Pengajaran berintikan interaksi antara dosen dan taruna. Dalam interaksi tersebut dosen melakukan kegiatan yang disebut mengajar, sedang taruna melakukan kegiatan yang disebut belajar (Ibrahim, 2010:13).

Bahasa Inggris merupakan bahasa international yang di gunakan oleh semua orang sebagai alat komunikasi antara satu negara dengan yang lainnya (Ummah, 2011:240). Mahasiswa perlu terus belajar untuk meningkatkan kemampuan Bahasa Inggris mereka. Belajar menurut pandangan kaum konstrukvisme adalah penyusunan pengetahuan dari pengalaman kongkrit, aktivitas kolaborasi dan refleksi serta interprestasi (Budiningsih, 2012:55). Mengajar adalah menata lingkungan agar taruna terminat dalam mengali makna serta menghargai ketidakmenentuan. Minat dari seseorang yang dapat mempengaruhi suatu keberhasilan. Hal tersebut menjadi indikator yang dipakai dalam penelitian. (Mulyasa, 2010:175).

Berdasarkan latar belakang masalah di atas, maka rumusan masalah dalam penelitian tindakan ini adalah: Bagaimana meningkatkan hasil belajar Modal Auxiliary melalui penggunaan Flipped classroom taruna Teknik Pesawat Udara Angkatan II C Poltekbang Surabaya? Penelitian tindakan ini bertujuan untuk mendeskripsikan upaya dosen dalam meningkatkan hasil belajar Modal Auxiliary melalui penggunaan Flipped classroom taruna Teknik Pesawat Udara Angkatan II C Poltekbang Surabaya. Hipotesis tindakan dalam 
penelitian ini adalah dengan menggunakan Flipped classroom, maka ada peningkatan hasil belajar Modal Auxiliary taruna Teknik Pesawat Udara Angkatan II C Poltekbang Surabaya. Adapun indikator keberhasilan yang ditetapkan di dalam penelitian ini adalah: (1) taruna Teknik Pesawat Udara Angkatan II C Poltekbang Surabaya mengalami ketuntasan belajar dalam materi Modal Auxiliary (nilai $\geq 75$ ), (2). kualitas pembelajaran meningkat dalam lembar observasi.

\section{METODE PENELITIAN}

Metode penelitian diperlukan dalam penelitian ini, untuk membantu alur pemikiran yang jelas pada jalannya penelitian. Penelitian ini menggunakan penelitian tindakan karena penelitian tindakan adalah merupakan penelitian yang lebih sesuai dengan tugas pokok dan fungsi guru, meningkatkan kualitas pembelajaran, meningkatkan kualitas siswa, serta mencapai tujuan pembelajaran atau pendidikan. PTK (Penelitian Tindakan Kelas) atau Classroom Action Research (CAR) yang merupakan bentuk kajian yang bersifat reflektif oleh pelaku tindakan, dilakukan untuk meningkatkan kematangan rasional dari tindakan-tindakan dalam melakukan tugas, memperdalam pemahaman terhadap tindakan-tindakan yang dilakukan itu, serta memperbaiki kondisi tempat pembelajaran tersebut dilakukan.

Pada setiap siklus, kegiatan yang dilakukan pada tahap perencanaan adalah: (a) melakukan pertemuan dengan teman sejawat selaku pengamat untuk membicarakan persiapan kegiatan pembelajaran yang dilakukan pada saat pembelajaran teks fungsional pendek mempergunakan Flipped classroom, (b) mendiskusikan dan menetapkan SAP yang akan diterapkan di kelas sebagai tindakan penelitian, (c) mempersiapkan bahan yang diperlukan untuk melaksanakan penelitian, (d) mempersiapkan waktu dan cara pelaksanaan, diskusi hasil pengamatan pada subyek penelitian, (e) mempersiapkan buku perekam data, (f) mempersiapkan perangkat tes hasil belajar pada siklus pertama.

Pelaksanaan tindakan pada setiap siklus adalah: (a) melaksanakan kegiatan pembelajaran berpedoman pada SAP yang telah dibuat. Secara lebih terinci sms penelitian yang diterapkan dapat dijelaskan sebagai berikut. Pembelajaran Modal Auxiliary menggunakan Flipped classroom dalam Bahasa Inggris pada siklus pertama dan pada siklus kedua pesan ditambah dengan tayangan Powerpoint untuk memperjelas flipped classroom. Kemudian, dosen mendiskusikan cara melaksanakan kegiatan pembelajaran dengan dosen pengamat. (b) melakukan penilaian menggunakan alat penilaian yang telah disediakan.

Kegiatan saat observasi adalah: (a) teman sejawat mencatat semua aktivitas yang dilakukan oleh dosen dan taruna selama proses pembelajaran, yaitu mulai kegiatan awal hingga kegiatan akhir. (b) melakukan observasi dengan instrumen observasi.

Kegiatan saat refleksi adalah: (a) menganalisa catatan di lapangan dan jurnal harian sebagai hasil pengamatan dikaji dan direnungkan kembali, (b) data yang terkumpul dikaji secara komprehensif, (c) data dibahas bersama pengamat untuk mendapat kesamaan pandangan terhadap tindakan pada siklus pertama. (d) hasil refleksi dijadikan bahan untuk merevisi rencana tindakan selanjutnya.

Penelitian ini menggunakan penelitian tindakan karena penelitian tindakan kelas adalah merupakan penelitian yang lebih sesuai dengan tugas pokok dan fungsi dosen, meningkatkan kualitas pembelajaran, meningkatkan kualitas taruna, serta mencapai tujuan pembelajaran atau pendidikan. Dalam penelitian ini yang menjadi subyek penelitian adalah 24 taruna Teknik Pesawat Udara Angkatan II C Poltekbang Surabaya Tahun Pelajaran 2016/2017. Penelitian ini dilaksanakan pada bulan Februari 2018. Metode pengumpulan data pada penelitian ini adalah observasi, tes, wawancara, dan catatan lapangan. Teknik analisis data yang dipergunakan adalah reduksi data, penyajian data, penarikan simpulan, serta verifikasi refleksi. 
Tes dilakukan untuk mengetahui Hasil belajar awal taruna sehingga peneliti dapat merencanakan tindakan yang akan diambil dalam memperbaiki proses pembelajaran. Pemberian tindakan dilakukan melalui tiga siklus dan evaluasi dilakukan diakhir siklus untuk mengetahui hasil belajar taruna pada setiap siklus. Tes adalah suatu alat pengumpul informasi, bersifat lebih resmi karena penuh dengan batasan-batasan (Arikunto, 2009:33). Hasil belajar dikatakan berhasil apabila taruna secara individual telah memperolah nilai 75 atau lebih, dan secara klasikal dikatakan tuntas belajar jika lebih dari $85 \%$ siswa mendapat nilai diatas 75. Di samping itu dilakukan juga metode analisis deskriptif yang merupakan pemaparan dari hasil penerapan pembelajaran dengan Flipped classroom.

\section{HASIL PENELITIAN}

Tabel 1. Deskripsi Hasil Belajar Bahasa Inggris Siklus Pertama

\begin{tabular}{|c|c|c|c|c|c|c|c|}
\hline No & can, could & may, might & must & shall, should & will & total & Nilai \\
\hline 1 & 1 & 1 & 1 & 1 & 0 & 4 & 80 \\
\hline 2 & 0 & 1 & 1 & 1 & 1 & 4 & 80 \\
\hline 3 & 1 & 1 & 1 & 1 & 1 & 5 & 100 \\
\hline 4 & 1 & 0 & 0 & 1 & 1 & 3 & 60 \\
\hline 5 & 1 & 0 & 1 & 0 & 1 & 3 & 60 \\
\hline 6 & 0 & 0 & 1 & 1 & 1 & 3 & 60 \\
\hline 7 & 0 & 0 & 1 & 1 & 1 & 3 & 60 \\
\hline 8 & 1 & 1 & 0 & 1 & 1 & 4 & 80 \\
\hline 9 & 0 & 1 & 1 & 1 & 1 & 4 & 80 \\
\hline 10 & 0 & 1 & 1 & 0 & 1 & 3 & 60 \\
\hline 11 & 1 & 1 & 1 & 1 & 0 & 4 & 80 \\
\hline 12 & 0 & 1 & 1 & 1 & 1 & 4 & 80 \\
\hline 13 & 1 & 1 & 0 & 0 & 1 & 3 & 60 \\
\hline 14 & 0 & 1 & 1 & 1 & 1 & 4 & 80 \\
\hline 15 & 1 & 1 & 0 & 1 & 1 & 4 & 80 \\
\hline 16 & 0 & 1 & 1 & 1 & 0 & 3 & 60 \\
\hline 17 & 0 & 1 & 1 & 0 & 1 & 3 & 60 \\
\hline 18 & 1 & 1 & 1 & 1 & 0 & 4 & 80 \\
\hline 19 & 1 & 1 & 0 & 1 & 1 & 4 & 80 \\
\hline 20 & 0 & 1 & 1 & 1 & 0 & 3 & 60 \\
\hline 21 & 0 & 1 & 1 & 0 & 1 & 3 & 60 \\
\hline 22 & 1 & 1 & 1 & 1 & 0 & 4 & 80 \\
\hline 23 & 0 & 1 & 1 & 1 & 1 & 4 & 80 \\
\hline 24 & 1 & 1 & 0 & 0 & 1 & 3 & 60 \\
\hline & & & & & & & 71,67 \\
\hline
\end{tabular}

Berdasarkan hasil penelitian, data tentang hasil belajar taruna pada saat siklus pertama disajikan pada tabel berikut ini. Berdasarkan data hasil penelitian pada siklus pertama mengenai hasil belajar bahasa Inggris taruna di bidang Modal Auxiliary dengan menggunakan metode demonsreasi, nilai tertinggi yang diperoleh responden adalah 100, nilai terendah adalah 40, dan nilai rata-rata hasil belajar bahasa Inggris adalah 71,67. Ketuntasan 11 taruna $(45,83 \%)$ 
Tabel 2. Deskripsi Hasil Belajar Bahasa Inggris Siklus Kedua

\begin{tabular}{|c|c|c|c|c|c|c|c|}
\hline No & can, could & may, might & must & shall, should & will & total & Nilai \\
\hline 1 & 1 & 1 & 1 & 1 & 1 & 5 & 100 \\
\hline 2 & 1 & 1 & 1 & 1 & 1 & 5 & 100 \\
\hline 3 & 1 & 1 & 1 & 1 & 1 & 5 & 100 \\
\hline 4 & 1 & 0 & 1 & 1 & 1 & 4 & 80 \\
\hline 5 & 1 & 0 & 1 & 1 & 1 & 4 & 80 \\
\hline 6 & 1 & 0 & 1 & 1 & 1 & 4 & 80 \\
\hline 7 & 1 & 0 & 1 & 1 & 1 & 4 & 80 \\
\hline 8 & 1 & 1 & 0 & 1 & 1 & 4 & 80 \\
\hline 9 & 1 & 1 & 1 & 1 & 1 & 5 & 100 \\
\hline 10 & 1 & 1 & 1 & 1 & 1 & 5 & 100 \\
\hline 11 & 1 & 1 & 1 & 1 & 1 & 5 & 100 \\
\hline 12 & 0 & 1 & 1 & 1 & 1 & 4 & 80 \\
\hline 13 & 1 & 1 & 0 & 1 & 1 & 4 & 80 \\
\hline 14 & 0 & 1 & 1 & 1 & 1 & 4 & 80 \\
\hline 15 & 1 & 1 & 0 & 1 & 1 & 4 & 80 \\
\hline 16 & 0 & 1 & 1 & 1 & 1 & 4 & 80 \\
\hline 17 & 0 & 1 & 1 & 1 & 1 & 4 & 80 \\
\hline 18 & 1 & 1 & 1 & 1 & 1 & 5 & 100 \\
\hline 19 & 1 & 1 & 0 & 1 & 1 & 4 & 80 \\
\hline 20 & 0 & 1 & 1 & 1 & 1 & 4 & 80 \\
\hline 21 & 0 & 1 & 1 & 1 & 1 & 4 & 80 \\
\hline 22 & 1 & 1 & 1 & 1 & 1 & 5 & 100 \\
\hline 23 & 0 & 1 & 1 & 1 & 1 & 4 & 80 \\
\hline 24 & 1 & 1 & 0 & 1 & 1 & 4 & 80 \\
\hline & & & & & & & 86,67 \\
\hline
\end{tabular}

Berdasarkan hasil penelitian, data tentang hasil belajar taruna pada saat siklus kedua disajikan pada tabel berikut ini. Berdasarkan data hasil penelitian pada siklus kedua mengenai hasil belajar bahasa Inggris taruna di bidang Modal Auxiliary dengan menggunakan metode demonsreasi ditambah dengan tayangan PowerPoint untuk memperjelas eksperimen, nilai tertinggi yang diperoleh responden adalah 100 , nilai terendah adalah 80 , dan nilai rata-rata hasil belajar bahasa Inggris adalah 86,67. Ketuntasan belajar 100\%. Kualitas proses pembelajaran selama siklus pertama, dan siklus kedua disajikan pada ketiga tabel berikut.

Tabel 3. Kualitas Proses Pembelajaran Selama Siklus Pertama

\begin{tabular}{|c|c|c|c|}
\hline NO & ASPEK & SKOR & KUALITAS \\
\hline 1. & Suasana Pembelajaran & 3.00 & Baik \\
\hline 2. & Tanggung Jawab & 3.00 & Baik \\
\hline 3. & Rasa Percaya Diri & 3.00 & Baik \\
\hline 4. & Fokus Kegiatan & 3.00 & Baik \\
\hline \multicolumn{2}{|c|}{$\begin{array}{c}\text { Rata-Rata Nilai } \\
\text { Kualitas Proses Pembelajaran }\end{array}$} & 3.00 & Baik \\
\hline
\end{tabular}


Tabel 4. Kualitas Pembelajaran Selama Siklus Kedua

\begin{tabular}{|c|c|c|c|}
\hline NO & ASPEK & SKOR & KUALITAS \\
\hline 1. & Suasana Pembelajaran & 4,00 & Sangat Baik \\
\hline 2. & Tanggung Jawab & 4.00 & Sangat Baik \\
\hline 3. & Rasa Percaya Diri & 4.00 & Sangat Baik \\
\hline 4. & Fokus Kegiatan & 4.00 & Sangat Baik \\
\hline \multicolumn{2}{|c|}{$\begin{array}{c}\text { Rata-Rata Nilai } \\
\text { Kualitas Proses Pembelajaran }\end{array}$} & 4.00 & Sangat Baik \\
\hline
\end{tabular}

Kriteria di atas yaitu yang mencakup suasana pembelajaran, tanggung jawab, rasa percaya diri, dan fokus kegiatan digunakan untuk mengetahui kualitas pembelajaran di dalam kelas.Tampaklah bahwa penggunaan Flipped classroom telah meningkatkan kualitas pembelajaran. Nilai rata-rata kualitas pembelajaran pada Siklus 1 sebesar 3,00, dan pada Siklus 2 adalah 4,00 .

\section{KESIMPULAN}

Simpulan yang dapat diambil dari penelitian ini adalah:

1. Taruna Teknik Pesawat Udara Angkatan II C Poltekbang Surabaya mengalami ketuntasan belajar dalam materi Modal Auxiliary (nilai $\geq 75$ ), Berdasarkan data hasil penelitian pada siklus pertama mengenai hasil belajar bahasa Inggris taruna di bidang Modal Auxiliary dengan menggunakan flipped classroom, nilai tertinggi yang diperoleh responden adalah 100, nilai terendah adalah 40, dan nilai rata-rata hasil belajar bahasa Inggris adalah 71,67. Pada siklus pertama flipped classroom dengan bantuan video. Berdasarkan data hasil penelitian pada siklus kedua mengenai hasil belajar bahasa Inggris taruna di bidang Modal Auxiliary dengan menggunakan flipped classroom ditambah dengan internet untuk memperjelas flipped classroom, nilai tertinggi yang diperoleh responden adalah 100 , nilai terendah adalah 80 , dan nilai rata-rata hasil belajar bahasa Inggris adalah 86,67. Pada siklus pertama ini yang tuntas ada 13 taruna $(54,17 \%)$ yang tidak tuntas ada 11 taruna $(45,83 \%)$. Pada siklus kedua yang tuntas ada 24 taruna $(100 \%)$.

2. Kualitas pembelajaran meningkat dalam lembar observasi. Kualitas pembelajaran yang mencakup suasana pembelajaran, tanggung jawab, rasa percaya diri, dan fokus kegiatan digunakan untuk mengetahui kualitas pembelajaran di dalam kelas. Tampaklah bahwa penggunaan Flipped classroom telah meningkatkan kualitas pembelajaran. Nilai ratarata kualitas pembelajaran pada siklus pertama sebesar 3.00, dan pada siklus dua adalah 4,00

\section{DAFTAR PUSTAKA}

Arikunto, Suharsimi. 2009. Dasar-Dasar Evaluasi Pendidikan. Jakarta:Bumi Aksara.

Azrinamey. 2013. Aktivitas-Aktivitas dalam Belajar. http://azrinamey.blogspot.com/2013/04/aktivitas-aktivitas-belajar.html

Budiningsih, Asri. 2012. Belajar \& Pembelajaran. Jakarta: Rineka Cipta

Chandra, Francisca. 2017. Implementasi Flipped classroom ddengan Video Tutorial pada Pembelajaan Fotografi Komesial. Jurnal Demandia, Vol. 02 No. 01 (Maret 2017): 2036.

Damayanti, Herry Novis. 2016. Efektifitas Flipped Clssroom Terhadp Sikap dan Ketrampilan Belajar Matematika di SMK. Jurnal Managemen Pendidikan - Vol. 11, No. 2, Januari 2016 : 2-8. ISSN: 1907-4034

Djamarah, Syaiful Bahri. 2012. Strategi Belajar Mengajar. Jakarta: PT Rineka Cipta 